\title{
STRATEGI PENDIDIKAN KARAKTER MELALUI MEDIA MIND MAPP UNTUK MENINGKATKAN HASIL BELAJAR SISWA
}

\author{
Nahdiyatul Ummah, M.Pd.I. \\ almasalfin@gmail.com
}

Siti Nurhayatin

sitinurhayatin98@gmail.com

\begin{abstract}
Abstrak
Dalam strategi pembelajaran beberapa siswa/i masih banyak kendala dalam meningkatkan hasil belajar terutama pada pendidikan karakter. Untuk mengatasi permasalahan tersebut guru harus bisa mengelola kelas dengan baik dengan menerapkan media mind mapp. Media Mind mapp merupakan cara untuk menyeimbangkan antara otak kanan dan otak kiri seseorang melalui pembuatan konsep yang menggunakan teknik curah gagasan dengan menggunakan kata kunci bebas, simbol atau gambar dan melukiskannya secara kesatuan disekitar tema tersebut. Penelitian ini adalah penelitian kepustakaan dengan menggunakan metode deskriptif. Hasil dari penelitian ini menunjukkan bahwa media mind mapp untuk meningkatkan hasil belajar siswa dapat membuat pendidikan karakter seseorang berkembang. Dalam media mind mapp membuat siswa/i menjadi pribadi yang kreatif, inovatif, mandiri, kerja keras dan bertanggungjawab. Sehingga siswa merasa nyaman ketika proses pembelajaran berlangsung.
\end{abstract}

\section{A. Pengantar}

Rata-rata di beberapa sekolah siswa/i nya banyak mengalami kendala pada penanaman karakter yang masih belum optimal. Hal ini terjadi pada saat siswa/i sedang mengikuti pelajaran yang berlangsung di dalam kelas, mereka tidak fokus pada meteri yang disampaikan guru dan mudah lupa dakan materi yang telah disampaikan sebelumnya. Dikarenakan seorang guru belum bisa mengelola kelas secara optimal, sehingga sebagian besar siswa/i belum mencapai kompetensi 
individual untuk mengikuti pelajaran dan menyebabkan ketidaknyamanan proses pembelajaran.

Strategi pembelajaran dari media Mind Mapp (peta pikiran) merupakan cara kreatif bagi siswa/i individu untuk memancing ide/mencatat hal-hal yang dipelajari dadapat membuat konsep baru. Media ini dapat memudahkan siswa/i dalam hal mengingat segala bentuk informasi dan memperlancar proses pembelajaran serta penyampaian materi. Karena tugas dari seorang guru dalam kegiatan pembelajaran di kelas adalah mengelola/memenej kelas menjadi kelas yang efektif dan efisien.

Disini penulis berharap, para siswa/i mampu menjadi karakter yang kreatif, tanggungjawab, displin, mandiri, kerja keras yang sesuai dengan kurikulum pendidikan karakter. Oleh sebab itu, kesuksesan materi pelajaran siswa/i dapat dilihat dari keberhasilan siswa melalui hasil belajarnya.

\section{B. Metodologi}

Penelitian ini berbentuk penelitian keputakaan. Dalam penelitian ini, peneliti menggunakan metode analisis deskriptif. Analisis deskriptif adalah suatu metode dengan jalan mengumpulkan data, menyusun atau mengklarifikasi, menganalisis dan menginterpretasikannya dengan tahapan-tahapan berikut:

1. Mengumpulkan sumber referensi yang berkaitan dengan masalah yang akan ditelti serta mempelajarinya.

2. Menganalisa ke sekolah untuk memperoleh data yang dibutuhkan kemudian diklarifikasikan sesuai dengan media mind mapp yang digunakan.

\section{Kajian Teori}

1. Pengertian Pendidikan Karakter

Pendidikan sering diartikan sebagai usaha manusia untuk membina kepribadiannya sesuai dengan nilai-nilai di dalam masyarakat dan kebudayaan. Pembelajaran di bidang pendidikan, lebih berfokus pada pencapaian materi saja dan hanya hanya sedikit yang menanamkan tercapai tetapi secara moralitas tidak bisa dipertanggungjawabkan.

Karakter adalah sikap pribadi yang stabil hasil dari proses konsolidasi secara profgresif dan dinamis, integrasi pernyataan dan tindakan.

Pendidikan di Indonesia sesuai dengan tujuan pendidikan nasional yaitu mewujudkan warga indonesia seutuhnya yang bukan hanya cerdas secara kognitif tetapi juga moralnya. Oleh karenan itu, penanaman karakter dalam proses pendidikan menjadi suatu kebutuhan mutlak. Pada tataran pendidikan tinggi dalam 
proses pembelajaran sehari-hari penanaman nilai karakter masih belum optimal. (Nina Oktarina, 2013)

2. Mind Mapp

a. Pengertian

Mind Mapp (peta pikiran) adalah suatu metode untuk memaksimalkan potensi manusia dengan menggunakan otak kanan dan otak kirinya secara simultan. Metode ini diperkenalkan oleh Tony Buzan pada 1974. (Alamsyah Said, 2017, hal. 172-173)

b. Strategi Mind Mapp

Penerapan metode mind mapp selain penggunaannya mencakup manajemen organisasi serta pengembangan diri, juga digunakan pada pembelajaran. Pemetaan pemikiran menggunakan berbagai teknik, misalnya dengan simbol atau gambar dan menggambarkannya pada satu konsep.

c. Prosedur Penerapan Strategi Mind Mapp

Menggunakan Mind Mapp dalam pembelajaran sangat mudah. Karena prinsip Mind mapp adalah perkembangan cabang-cabang dimulai dari sentral informasi yang ditulis pada bagian tengah kertas. Pembelajaran ini sangat cocok untuk me-review pengetahuan awal siswa.

d. Rekomendasi Penerapan Strategi Mind Mapp

Mengajar dengan menggunakan mind mapp membantu siswa/i mengembangkan pikiran dalam suatu rangkaian yang terhubung dan ini memberikan penekanan pada siswa/i bahwa semakin banyak informasi yang diketahui dan dipahaminya maka semakin mudah siswa membuat mind mapp materi.

e. Pendekatan Kecerdasan jamak dan Modalitas Belajar

Penggunaan strategi mengajar guru menggunakan media mind mapp mampu memberikan pengalaman bermakna bagi siswa/i, siswa tersebut dapat merangkai cabang-cabang perkembangan pengetahuan yang dipahaminya dalam bentuk area-area terhubung, diantara area itu siswa bisa memberikan penjelasan singkat terhadap submateri. Kemampuan siswa merangkai pengetahuan dalam bentuk garis-garis cabang melibatkan kemampuan spasialvisual siswa. Proses pembentukan cabang dipengaruhi oleh daya ingat, logismatematis. (Alamsyah Said, 2017, hal. 172-173)

\section{Diskusi/pembahasan}


Penelitian ini bertujuan untuk mengetahui pengaruh strategi pemebelajaran melalui media Mind mapp terhadap hasil belajar siswa. Strategi pembelajaran Mind Mapp (peta pikiran) merupakan cara kreatif bagi siswa/i individu untuk memancing ide mencatat hal-hal yang dipelajari atau merencanakan konsep baru.

1. Pengaplikasian Mind Mapp dalam kegiatan pembelajaran

Berdasarkan hasil kajian pustaka di atas, terlihat bahwa ada banyak manfaat yang dapat diperoleh dari penerapan media Mind Mapp. Salah satu yang paling menarik adalah bahwa Mind Mapp menyeimbangkan kedua belah otak, yaitu antara logika dan imajinasi. Melalui pengaplikasian Mind Mapp, siswa/i dapat menghasilkan lebih banyak ide, pembelajaran menjadi menyenangkan, dan dapat memudahkan dalam memahami materi yang telah disampaikan.

Langkah-langkah pengaplikasian media mind mapp dalam pembelajaran yaitu untuk meningkatkan hasil belajar siswa/i, bukan hanya sebuah metode yang dilakukan tanpa manajemen yang jelas. Oleh karena itu, guru harus berusaha untuk memberikan pertimbangan yang baik tentang apa yang akan dilakukan dalam kelas untuk mendapatkan hasil yang sesuai indikator yang ingin dicapai.

2. Hasil pengaplikasian Mind Mapp pada pendidikan karakter

Mind Mapp (peta pikiran) adalah cara termudah untuk menempatkan informasi kedalam otak dan mengambil informasi ke luar dari otak. Strategi pembelajaran Mind mapp adalah cara mencatat yang efektif, kreatif dan dapat menyeimbangkan otak kanan dan otak kiri. Karena dalam pembuatann Mind mapp terdapat penggabungan antara warna, simbol, garis, kata serta imajinasi dalam menghubungkan suatu konsep materi. Hal ini yang secara alami dapat mengaktifkan otak kanan dan kiri yang menurut teori dapat menguatkan ingatan terhadap sesuatu. Dari penguatan ingatan inilah yang diharapkan dapat meningkatkan hasil belajar siswa/i.

\section{E. Penutup/kesimpulan}

1. Kesimpulan

Setelah menganalisis penggunaan strategi pendidikan karakter melalui media Mind Mapp dalam meningkatkan hasil belajar siswa, peneliti dapat menyimpulkan:

a. Media mind mapp merupakan cara untuk menyeimbangkan antara otak kanan dan otak kiri seseorang dalam proses pembelajaran berlangsung. 
b. Dalam media mind Mapp terlihat bahwa media ini mempermudah siswa/i dalam proses mengingat yang dapat mengembangkan pendidikan karakter dari hasil belajar mereka di sekolah.

2. Saran

Untuk mencapai kesempurnaan dan tercapainya tujuan dari hasil ini, peneliti memberikan beberapa saran, diantaranya:

1. Guru diharapkan mampu menggunakan strategi pembelajaran yang lebih kreatif dari yang sebelumnya, dan menggunakan metode yang sesuai dengan mata pelajaran sekaligus kebutuhan siswa/i. Penggunaan strategi pembelajaran yang aktif, kreatif serta bervariasi tentunya dapat meminimalisir kejenuhan siswa/i dalam proses belajar mengajar. Sehingga siswa/i menjadi lebih aktif dalam proses pembelajaran berlangsung.

2. Peserta didik diharapkan lebih aktif dan bersemangat dalam mengikuti proses belajar mengajar semua mata pelajaran. Oleh karena itu, diperlukan pendekatan belajar yang baik dari seorang pendidik dalam mengelola kelas sehingga mempengaruhi hasil belajar peserta didiknya.

\section{DAFTAR PUSTAKA}

Alamsyah Said, A. B. (2017). 95 Strategi mengajar Multiple Intellegences-Mengajar Sesuai kerja otak dan gaya belajar siswa. Jakarta: Kencana.

Nina Oktarina, A. k. (2013). Strategi Pendidikan Karakter melalui Mind Mapping. Jurnal Penelitian Pendidikan, XXX. 
